\title{
Potassium Fertilization Role in Tomato Tolerance of Water Salinity and Stress under Drip Irrigation System Abdel-Mageed, Y. T. ${ }^{1}$; H. A. Hassan ${ }^{2}$; A. F. Abdel-Rahim ${ }^{3}$; M. M. Abd EL- Azeim ${ }^{2}$ and M. A. Matouk ${ }^{2}$ \\ ${ }^{1}$ Department of Horticulture, Faculty of Agriculture, Minia University, Egypt \\ ${ }^{2}$ Department of Soil Sciences, Faculty of Agriculture, Minia University, Egypt \\ ${ }^{3}$ Central Laboratory, Faculty of Agriculture, Minia University, Egypt \\ Corresponding author: Hassan Ali Hassan - hassan.metwaly@mu.edu.eg
}

\section{ABSTRACT}

A study was carried out on a field scale during two successive growth seasons (2009/2010 and 2010/2011) on tomato plants irrigated with saline ground water $\left(2.24\right.$ and $\left.3.86 \mathrm{dS} \mathrm{m}^{-1}\right)$ using drip irrigation system, subjected to water stress (irrigation every 3 , 4, and 5 days), and were grown under application of potassium fertilization (96, 120, and $144 \mathrm{~kg} \mathrm{~K}_{2} \mathrm{O}$ /feddan) in newly reclaimed lands at the Agricultural Experiments and Research Center, Faculty of Agriculture, Minia University, El-Minia Governorate, Egypt. The current study aims to investigate the effects of irrigation water salinity and water stress on tomato growth, tomato yield, and tomato fruit quality under application of a salinity and water stress alleviated amendment (potassium fertilization) using drip irrigation system. The obtained results of the current study showed that increasing irrigation water salinity level from $2.24 \mathrm{dS} \mathrm{m}^{-1}$ to $3.86 \mathrm{dS} \mathrm{m}^{-1}$ decreased tomato plant height, tomato shoots fresh weight, average tomato fruit weight, fresh tomato fruit yield, and tomato fruit dry weight, while, it increased tomato shoots dry weight, number of tomato fruits per plant, total soluble solids of tomato, and tomato fruits marketability (shelf life) in growth seasons. Increasing irrigation interval from 3 up to 5 days decreased tomato shoots fresh weight in both growth seasons, however, it increased tomato shoots dry weight, total soluble solids, and tomato fruits marketability in the two growth seasons. Increasing the potassium fertilization level from 96 up to $144 \mathrm{~kg} \mathrm{~K}_{2} \mathrm{O} /$ feddan increased the tomato plant height, tomato shoots dry weight, average tomato fruit weight, total soluble solids of tomato, and tomato fruits marketability. Increasing the potassium fertilization level from 96 to 120 or $144 \mathrm{~kg} \mathrm{~K}_{2} \mathrm{O} /$ feddan increased the tomato shoots fresh weight, number of tomato fruits per plant, fresh tomato fruit yield, and tomato fruit dry weight in the two growth seasons. The increase in the tomato plant height, tomato shoots fresh weight, tomato shoots dry weight, number of tomato fruits per plant, average tomato fruit weight, fresh tomato fruit yield, total soluble solids of tomato, tomato fruits marketability, and tomato fruit dry weight implies that application of potassium fertilization to soil alleviated adverse effects of salinity stress and water stress on tomato growth, tomato yield, and tomato fruit quality. The results of the current research indicated that it can be recommended that to alleviate and manage adverse effects of salinity stress and water stress on tomato growth, tomato yield, and tomato fruit quality, good cultural practices management to be followed are: (1) irrigate tomato plants every 4 days, (2) apply appropriate and optimized requirements of potassium fertilization to soils $\left(120 \mathrm{~kg} \mathrm{~K} \mathrm{~K}_{2} \mathrm{O} / \mathrm{feddan}\right)$, and (3) use drip irrigation system as an irrigation management which might control soil salinity build-up and soil water content since it can keep a high soil water content and low salt concentration in the root zone.

Keywords: Salinity, intervals, potassium, tomato, drip irrigation

\section{INTRODUCTION}

Egypt lies in the arid region of the world. Therefore, the agriculture depends on the irrigation mainly from the river Nile and from the ground water in some areas of the irrigated lands. The population in Egypt is increasing year after year which requires the cultivation of the newly reclaimed lands to increase the cultivated lands and consequently, increase the food production for the national food security. Water is an important resource for the sustainable agricultural development in Egypt. The scarcity of the fresh water resources in Egypt led to the use of saline water for irrigation. Use of the saline water for irrigation has adverse effects on the soil properties, plant growth, and crop yield and quality. Tomato is one of the most important vegetable crops grown in Egypt.

There are different managements for alleviating salinity and water stress. Fertilization management by applying potassium fertilization under drip irrigation system is the management which is preferred to be used to alleviate deleterious effects of salinity and water stress on tomato crop. Potassium is an essential nutrient for the physiological and biochemical processes in the plant. Potassium has physiological functions which enable the plant to tolerate the biotic and abiotic stresses especially the salinity and water stress. The use of the drip irrigation system provides a suitable soil moisture content for the plant which lead to a better growth and yield and maintains low salt accumulation in the wetting zone. Therefore, the drip irrigation system provides a good advantage when using the saline water for irrigation.

El Bedawy (2014) indicated that water is one of the most important inputs for economic development and sustainable development; as the demand increases, so too does the importance of water. The future looks miserable if Egypt does not succeed in formulating and implementing water resources management approach which can match the limited freshwater supply with the increasing demand. Saad et al. (2013) reported that as a result of the shortage in the good quality irrigation water resources, the unconventional sources such as the drainage water, treated wastewater, and brackish water are being increasingly used in the agriculture. Their utilization provides new sources of water for more food production. Irrigation with the saline water requires larger and more frequent applications than irrigation with the good quality water.

Food productivity is decreasing due to impact of various biotic and abiotic stresses; therefore, minimizing these losses is a major area of concern for all nations to cope with the increasing food requirements. Salinity and drought are among abiotic major stresses, which adversely affect plant growth and productivity (Hasanuzzaman et al., 2018). Mahajan and Tuteja (2005) pointed out that salinity and drought are among the major stresses, which drastically affect the plants growth and productivity. The salinity and drought exert their nasty effect mainly by disrupting the osmotic and ionic balance of plant cells. Osman (2018) indicated that salinity is a well-known factor 
affecting negatively growth and production of many crops such as tomato. The main negative effect of salinity comes from the osmotic effect on the plant water uptake which eventually affects the growth and yield. Mahajan and Tuteja (2005) reported that water stress may arise as a result of two conditions, either due to excess of water or water deficit. The more common water stress encountered is the water deficit stress known as the drought stress.

A customary vegetable like tomato, which is the most important vegetable worldwide, can fully fit the requirements for a balanced diet. It contains a series of beneficial health compounds and can be easily integrated in the daily nutrition: Besides their fresh uptake, the consumers use tomatoes in soups, sauces, pizza, pasta, and many other dishes (Krauss et al., 2006). According to the relative salt tolerance of the agricultural crops (Maas, 1984), tomato (Lycopersicon lycopersicum) is moderately sensitive (Ayers and Westcot, 1994). Cuartero and Fernandez-Munoz (1999) indicated that tomato could act as a model crop for saline land recovery and use of poorquality water as there is a wealth of knowledge of the physiology and genetics of this species. Imana et al. (2010) demonstrated that water management is a key factor that can influence the tomato production since the crop is affected by both deficit and surplus irrigation water. Bringing the optimum irrigation water to the crop might reduce the field losses during production.

Brackish and saline water resources not used nowadays could be employed for the irrigation if greater knowledge of salt tolerance and proper technology are developed (Zayton et al., 2009). Many factors have played a great role in the agricultural development. One important factor is the fertilization. Applying an adequate quantity of the right quality is the key for the improved plant growth and production. Potassium $(\mathrm{K})$ is a major element for the plant nutrition (Krauss, 2003). Wang et al. (2013) reported that maintaining an optimum $\mathrm{K}$ nutritional status is essential for the plant resistance to biotic and abiotic stresses. Balanced fertilization and efficient $\mathrm{K}$ usage in combination with other nutrients not only contribute to the sustainable crop's growth, yield and quality, but also influence the plant health and reduce the environmental risks. Malakouti et al. (2003) showed that potassium $(\mathrm{K})$ is vital for many plant processes and it is required to activate at least 60 enzymes involved in plant growth. Potassium improves the crop yield and quality. It relieves water, salt and drought stresses, hence $\mathrm{K}$ reduces the crop water requirement. Because $\mathrm{K}$ has a dominant role in the opening and closing of the stomata, through which water is transpired from the leaves and $\mathrm{CO}_{2}$ enters the leaves. Malash et al. (2008) concluded that salinity of irrigation water restricted the plant growth and decreased the fruit yield by reducing both the fruit weight and number. The results of this study recommend the use of drip irrigation in general and under saline condition in particular, as the tomato fruit yield and yield per unit of water used were higher than when using the furrow irrigation. In addition to maintaining ideal water levels, the drip irrigation reduced the salinity accumulation in the root zone, which in turn reduced $\mathrm{Na}, \mathrm{Cl}$, and $\mathrm{Mg}$ uptake and minimized their content in the leaves, in such a way reduces the salinity hazards in the drip irrigated plants than those furrow irrigated.
Keeping in mind the prevailing facts and results, the current study aims to investigate the effects of irrigation water salinity and water stress on tomato growth, tomato yield, and tomato fruit quality under application of a salinity and water stress alleviated amendment (potassium fertilization) using drip irrigation system. Therefore, the investigated aspects in terms of relation to tomato crop production were as follows:

1- Effects of salinity and water stress on tomato growth (health) (Lycopersicon esculentum L.) of Founa 734 variety.

2- Effects of salinity and water stress on tomato yield and tomato fruit quality.

3- Effects of different potassium fertilization levels on tomato yield and tomato fruit quality.

\section{MATERIALS AND METHODS}

\section{Experimental site description}

The current study was carried out on a field scale during two successive growth seasons (2009/2010 and 2010/2011) on the tomato plants which were irrigated with ground water using the drip irrigation system, subjected to the water stress, and were grown under application of the potassium fertilization in the newly reclaimed lands at the Agricultural Experiments and Research Center, Faculty of Agriculture, Minia University. The Agricultural Experiments and Research Center is located in the West district of Samalout, El-Minia Governorate, Egypt. The area under investigation is located in the Western Desert $\left(28^{\circ} 18^{\prime} 16^{\prime \prime} \mathrm{N}\right.$, $\left.30^{\circ} 34^{\prime} 38^{\prime \prime} \mathrm{E}\right)$ and lies in arid and semi-arid region characterized with an evaporation rate of $4897.91 \mathrm{~mm} /$ year.

Soil characterization of the experimental site

Soil of the experimental site was a virgin sandy soil and it was not cultivated with any field crop before the current study. Therefore; as an attempt to elevate the soil fertility and enhance the soil quality for tomato plant growth, repeated large amounts of clay was transferred to the soil surface of the experimental site in May 2009 and mixed with this sandy soil at the depth of $0.0-30 \mathrm{~cm}$, thus, the texture of its surface $(0.0-30 \mathrm{~cm})$ was converted from sandy into loam.

Sustainable development in the Western Desert of El-Minia Governorate is controlled by availability and quality of soil and groundwater resources. Physicochemical soil properties of the uncultivated soils which is located at the experimental site in the Western Desert, Egypt, must be characterized before cultivating tomato and irrigation of tomato with saline groundwater in order to observe their effects on the tomato growth, tomato yield, and tomato fruit quality. Therefore, a representative soil sample was collected from the surface soil of the experimental site at the depth of 0.0-30 $\mathrm{cm}$. The soil sample was collected two times from each plot before tomato cultivation and at the end of two growth seasons. The soil sample was left on the air until completely air dried at the room temperature, crushed, and sieved to pass through a $2.0 \mathrm{~mm}$ stainless steel sieve. The sieved soil was mixed thoroughly and a subsample was taken and analyzed for the $\mathrm{pH}$, electrical conductivity (E.C.), organic matter (O.M.), calcium carbonate, total nitrogen, available phosphorus, available potassium, soluble cations (calcium, magnesium, sodium, and potassium), soluble anions (chloride, sulphate, carbonate, and bicarbonate), 
particle size distribution, water holding capacity, field capacity, wilting point, and available water. The soil analysis was performed using standard methods as described by Jackson (1973), Black et al. (1965), page et al. (1982), and Avery and Bascomb (1982). Some chemical and physical properties of the surface soil at the depth of $0.0-30 \mathrm{~cm}$ before cultivating the tomato seedlings in the first growth season are shown in Table 1.

Table 1. Some chemical and physical properties of the investigated soil before tomato cultivation in the first growth season.

\begin{tabular}{|c|c|}
\hline Soil properties & Value \\
\hline $\begin{array}{l}\text { pH } \\
\text { E.C. }\left(\mathrm{dS} \mathrm{m}^{-1}\right) \\
\text { Organic matter }(\%) \\
\text { CaCO }_{3}\left(\mathrm{~g} \mathrm{~kg}^{-1}\right) \\
\left.\text { Total } \mathrm{N}^{-1}\right) \\
\text { Available } \mathrm{P}\left(\mathrm{mg} \mathrm{kg}^{-1}\right) \\
\text { Available K}\left(\mathrm{mg} \mathrm{kg}^{-1}\right)\end{array}$ & $\begin{array}{c}8.15 \\
1.89 \\
1.18 \\
39.2 \\
1.5 \\
14.32 \\
23.20 \\
\end{array}$ \\
\hline $\begin{array}{l}\text { Soluble cations: } \\
\text { Soluble } \mathrm{Ca}^{2+}\left(\mathrm{mg} \mathrm{kg}^{-1}\right) \\
\text { Soluble } \mathrm{Mg}^{2+}\left(\mathrm{mg} \mathrm{kg}^{-1}\right) \\
\text { Soluble Na }\left(\mathrm{mg} \mathrm{kg}^{-1}\right) \\
\text { Soluble } \mathrm{K}^{+}\left(\mathrm{mg} \mathrm{kg}^{-1}\right)\end{array}$ & $\begin{array}{l}134.0 \\
61.1 \\
80.0 \\
14.7\end{array}$ \\
\hline $\begin{array}{l}\text { Soluble } \mathrm{Cl}^{-}\left(\mathrm{mg} \mathrm{kg}^{-1}\right) \\
\text { Soluble } \mathrm{SO}_{4}^{L^{--}}\left(\mathrm{mg} \mathrm{kg}^{-1}\right) \\
\text { Soluble anions: } \mathrm{CO}_{3}^{{ }^{-}}\left(\mathrm{mg} \mathrm{kg}^{-1}\right) \\
\text { Soluble } \mathrm{HCO}_{3}^{-}\left(\mathrm{mg} \mathrm{kg}^{-1}\right) \\
\end{array}$ & $\begin{array}{l}113.2 \\
145.3 \\
25.0 \\
105.9\end{array}$ \\
\hline $\begin{array}{l} \\
\text { Physical properties: } \\
\text { Clay }(\%) \\
\text { Silt }(\%) \\
\text { Sand (\%) } \\
\text { Texture grade } \\
\text { Water Holding Capacity }(\%) \\
\text { Field Capacity (\%) } \\
\text { Wilting Point }(\%) \\
\text { Available Water }(\%)\end{array}$ & $\begin{array}{l}24.25 \\
31.40 \\
44.35 \\
\text { Loam } \\
35.66 \\
29.43 \\
9.55 \\
19.88\end{array}$ \\
\hline
\end{tabular}

\section{Climatic conditions of the experimental site}

The climate in Egypt is generally moderate; it is mostly hot or warm during the day, and cool at night. In the deserts, the temperatures vary considerably especially in summer; when they may range from $7{ }^{\circ} \mathrm{C}$ at night, to 52 ${ }^{\circ} \mathrm{C}$ during the day. While the winter temperatures in the deserts do not fluctuate so wildly, they can be as low as 0 ${ }^{\circ} \mathrm{C}$ at night, and as high as $18{ }^{\circ} \mathrm{C}$ during the day. Egypt receives less than $80 \mathrm{~mm}$ of precipitation annually in most areas, although in the coastal areas it reaches $200 \mathrm{~mm}$. It hardly ever rains during the summer (El-Nahrawy, 2011).

\section{Irrigation water management \\ Source of irrigation water}

The experimental field was drip irrigated from two well waters which were different in their salinities. The experimental field area was divided into two main plots, one main plot was irrigated with the well water No. 1 of $2.24 \mathrm{dS} \mathrm{m}^{-1}$ and the second main plot was irrigated with the well water No. 2 of $3.86 \mathrm{dS} \mathrm{m}^{-1}$.

\section{Evaluation of the ground water quality}

Before the tomato cultivation in the two growth seasons, water samples of two wells available for irrigation in the Agricultural Experiments and Research Center, Western Desert of El-Minia Governorate, were analyzed for their chemical composition and characteristics and were evaluated to assess their suitability for irrigation of the tomato plants and to predict and observe their effects on the tomato growth, tomato yield, and tomato fruit quality. At each irrigation event in two growth seasons, water sample was collected from each well water in a clean and dried plastic bottle, filtered and stored at $4.0{ }^{\circ} \mathrm{C}$ until analysis, which was performed immediately, or preserved in accordance with American Public Health Association (APHA, 2012). Well water sample was analyzed for $\mathrm{pH}$, salinity (E.C. and TDS), soluble cations (calcium, magnesium, sodium, and potassium), and soluble anions (chloride, sulphate, carbonate, and bicarbonate) as described by Chapman and Pratt (1961) and standard methods of the American Public Health Association (APHA, 2012). Chemical analysis of well water parameters such as $\mathrm{pH}$, E.C., and TDS were performed in the field and laboratory using portable digital meters model (Hanna Instruments, Michigan, USA) (APHA, 2012). The chemical composition and criteria of the two well waters which were used for irrigation of the tomato plants during two growth seasons are summarized in Table 2.

Concerning the water classification by salinity, as can be seen in Table 3 and according to Phocaides (2000); the well water No. 1 is classified as a slightly saline water and the well water No. 2 is classified as a medium saline water.

Table 2. Chemical composition and criteria of the two well waters which were used for irrigation of the tomato plants during the two growth seasons.

\begin{tabular}{|c|c|c|}
\hline $\begin{array}{l}\text { Chemical composition } \\
\text { and criteria }\end{array}$ & $\begin{array}{c}\text { Well water } \\
\text { No. } 1 \\
\end{array}$ & $\begin{array}{c}\text { Well water No. } \\
\mathbf{2}\end{array}$ \\
\hline $\begin{array}{l}\text { Ph } \\
\text { E.C. }\left(\mathrm{dS} \mathrm{m}^{-1}\right)\end{array}$ & $\begin{array}{c}\text { composition: } \\
7.91 \\
2.24\end{array}$ & $\begin{array}{l}8.12 \\
3.86\end{array}$ \\
\hline $\begin{array}{l}\text { Sol } \\
\text { Soluble } \mathrm{Ca}^{L^{+}}(\mathrm{meq} / \mathrm{l}) \\
\text { Soluble } \mathrm{Mg}^{2+}(\mathrm{meq} / \mathrm{l}) \\
\text { Soluble } \mathrm{Na}^{+}(\mathrm{meq} / \mathrm{l}) \\
\text { Soluble } \mathrm{K}^{+}(\mathrm{meq} / \mathrm{l}) \\
\end{array}$ & $\begin{array}{c}\text { le cations: } \\
14.04 \\
3.62 \\
4.17 \\
0.40 \\
\end{array}$ & $\begin{array}{l}20.30 \\
11.82 \\
5.73 \\
0.56 \\
\end{array}$ \\
\hline $\begin{array}{l}\text { Soluble } \mathrm{Cl}^{-}(\mathrm{meq} / \mathrm{l}) \\
\text { Soluble } \mathrm{SO}_{4}{ }^{--} \text {(meq/l) } \\
\text { Soluble } \mathrm{CO}_{3}{ }^{--}(\mathrm{meq} / \mathrm{l}) \\
\text { Soluble } \mathrm{HCO}_{3}^{-}(\mathrm{meq} / \mathrm{l}) \\
\end{array}$ & $\begin{array}{c}\text { e anions: } \\
9.27 \\
11.16 \\
0.00 \\
1.80 \\
\end{array}$ & $\begin{array}{c}12.42 \\
22.39 \\
0.00 \\
3.60\end{array}$ \\
\hline $\begin{array}{l}\text { S.A.R. } \\
\mathrm{Ca}^{2+} / \mathrm{Mg}^{2+} \text { Ratio }\end{array}$ & $\begin{array}{c}\text { cal criteria: } \\
1.40 \\
3.88 \\
\end{array}$ & $\begin{array}{l}1.43 \\
1.72 \\
\end{array}$ \\
\hline
\end{tabular}

\section{Irrigation scheduling}

The irrigation of the tomato plants was scheduled in different irrigation intervals to subject the tomato plants to the water stress. The irrigation intervals treatments of the tomato plants were irrigation of the tomato plants every 3 , 4 , and 5 days.

\section{Irrigation system}

The current study was conducted in the newly reclaimed lands, which are mostly characterized in texture as sandy or sandy calcareous soils. The irrigation systems which are preferable to be used to irrigate these lands are the modern irrigation systems. One of these modern irrigation systems, which is suitable for the tomato irrigation is the drip irrigation system because it has many advantages.

The drip irrigation network was established in the experimental field for irrigation of the tomato plants. Each drip lateral line contained seven GR-type emitters at $50 \mathrm{~cm}$ spacing with the water discharge at $4 \mathrm{~L} / \mathrm{hr}$ every irrigation. The drip irrigation network was used in the two growth seasons. 


\section{Experimental design}

The experimental design was factorial in a completely randomized block design (in a split-split-plot) with three replicates. The experimental design included two levels of the irrigation well water salinity, three treatments of the irrigation intervals, and three levels of potassium fertilization; which were applied singly or in combination, making a total number of eighteen treatments of all.

Treatments of the experimental design were as follows:

1- Two levels of the irrigation well water salinity (well water No. 1 of $2.24 \mathrm{dS} \mathrm{m}^{-1}$ and well water No. 2 of 3.86 $\mathrm{dS} \mathrm{m} \mathrm{m}^{-1}$ ), which were denoted as $\mathrm{S}_{1}$ and $\mathrm{S}_{2}$, respectively.

2- Three treatments of the irrigation intervals (irrigation of the tomato plants every 3,4 , and 5 days), which were denoted as $T_{1}, T_{2}$, and $T_{3}$, respectively.

3- Three levels of the potassium fertilization (96, 120, and $144 \mathrm{~kg} \mathrm{~K} \mathrm{~K}_{2} \mathrm{O}$ /feddan), which were denoted as $\mathrm{K}_{1}, \mathrm{~K}_{2}$, and $\mathrm{K}_{3}$, respectively.

The total experimental field area was $1000 \mathrm{~m}^{2}$. The experimental design consisted of 54 sub-sub plots in the two growth seasons of tomato. The total experimental field area was divided into two main plots, one main plot was allocated for the irrigation with the well water No. 1and the second main plot was allocated for the irrigation with the well water No. 2. Each main plot of the irrigation well water salinity treatments consisted of three experimental sub plots (irrigation intervals treatments). Each sub plot of the irrigation intervals treatments consisted of nine experimental sub - sub plots (three levels of the potassium fertilization $\mathrm{X}$ three replicates). The size of each sub - sub plot was $10.5 \mathrm{~m}^{2}(3.5 \times 3.0 \mathrm{~m}=1 / 400$ of the feddan area). Each sub - sub plot included 6 rows for the tomato seedlings cultivation. The tomato seedlings spacing was 50 $\mathrm{cm}$ apart between the rows. The experimental design of the second growth season $(2010 / 2011)$ was similar to that of the first growth season $(2009 / 2010)$.

\section{Experiment procedure}

The soil of the experimental field was prepared for tomato cultivation in the two tomato growth seasons. The soil of the experimental field was refined to make it a suitable bed for tomato seedlings. Soil of each sub-sub plot was ridged at $50 \mathrm{~cm}$ apart between the rows. To prevent the water seepage from each sub - sub plot to adjacent sub - sub plot, a $1.0 \mathrm{~m}$ spacing was left between all the sub sub plots of each irrigation intervals treatment as well as a $2.0 \mathrm{~m}$ spacing was left as a border line between each irrigation intervals treatment and the adjacent irrigation intervals treatment.

The phosphorus fertilization was applied to the soil of all the sub - sub plots in the form of calcium superphosphate $\left(15.5 \% \mathrm{P}_{2} \mathrm{O}_{5}\right)$ at the standard recommended rate of $150 \mathrm{~kg}$ calcium superphosphate/feddan during the soil preparation.

\section{Set up of the field experiment}

After applying the phosphorus fertilization to the soil of all the sub - sub plots, the experimental design was established. All sub - sub plots of the experiment were irrigated for 3 hours to cultivate the tomato seedlings. 21 and 24 days old of tomato seedlings (Lycopersicon esculentum L.) of Funa 734 variety were cultivated in the $5^{\text {th }}$ of September 2009 and in the $12^{\text {th }}$ of September 2010 in the first and the second growth seasons, respectively. The replanting was done in the two growth seasons.

The nitrogen fertilization was applied to the soil for all sub-sub plots as ammonium nitrate $(33.5 \% \mathrm{~N})$ at the standard recommended rate of $200 \mathrm{~kg}$ ammonium nitrate/feddan in three doses.

The respected levels of the potassium fertilization were applied to the soil of all the plots as potassium sulphate $\left(48 \% \mathrm{~K}_{2} \mathrm{O}\right)$. The potassium fertilization levels were 200,250 , and $300 \mathrm{~kg}$ potassium sulphate/feddan which give 96, 120, and $144 \mathrm{~kg} \mathrm{~K}_{2} \mathrm{O} /$ feddan, respectively. The potassium fertilization levels were applied in three doses as follows:

1- The first dose (20\% of each respected level) was applied after one month of the tomato cultivation date.

2- The second dose ( $40 \%$ of each respected level) was applied one month after the first dose.

3 - The final dose $(40 \%$ of each respected level) was applied after one month after the second dose.

A minimum tillage was done in the two growth seasons. The tomato plants were sprayed with Lannate pesticide to tolerate the whitefly (Bemisia tabaci).

All the agricultural practices except the irrigation intervals treatments and potassium fertilization levels were applied as commonly used for growing tomato in the desert agriculture in the two growth seasons.

\section{Tomato harvest and end of the field experiment}

A representative sample of the tomato plants was identified from an area of $1.0 \mathrm{~m}^{2}$ of each sub-sub plot. The area of $1.0 \mathrm{~m}^{2}$ of each sub-sub plot was randomly chosen from middle of each sub-sub plot. The area of $1.0 \mathrm{~m}^{2}$ of each sub-sub plot contains four tomato plants.

The fresh tomato fruits were harvested at the physiological maturity stage from the four tomato plants twice or three times weekly depending upon the quantity of matured fruits. In each time of tomato fruits harvest during the harvest period, fresh tomato fruits of the four tomato plants were collected, weighed to record the fresh tomato yield, and counted to record the number of fruits per plant.

At 100 days from the tomato seedlings cultivation date, the tomato plant height was recorded. Also, fresh tomato fruits of the four tomato plants were collected, weighed to record the fresh tomato yield, counted to record the number of fruits per plant. A representative sample of the tomato fruits was taken from fruits of the four tomato plants to determine the tomato fruits quality parameters and chemical composition of tomato plants. The total soluble solids (T.S.S.) of the tomato fruit juice was determined at the field using hand refractometer, while, the tomato fruits marketability [shelf life duration (days)] was performed at the laboratory. Then, the tomato fruits were dried in the oven at $65{ }^{\circ} \mathrm{C}$ and weighed to record the dry weight of the tomato fruits. The dry weight of the tomato fruits was recorded as $\mathrm{kg} / \mathrm{plot}$ by weighing. The dry weight of the tomato fruits was calculated as ton/feddan taking in consideration that the feddan area is $4200 \mathrm{~m}^{2}$ not $3600 \mathrm{~m}^{2}$.

At the end of tomato harvest, the fresh weight of the tomato fruit yield was recorded as $\mathrm{kg} / \mathrm{plot}$ by weighing and was converted to ton/feddan taking into consideration that the feddan area is $4200 \mathrm{~m}^{2}$ not $3600 \mathrm{~m}^{2}$. Average fruit weight was calculated by dividing the total weight of all fresh tomato fruits which were collected from each four 
tomato plants during the harvest period by the total fruits number of the four tomato plants. A representative sample of the tomato shoots was taken from shoots of the four tomato plants to determine the chemical composition of tomato shoots. The fresh weight of the tomato shoots was recorded by weighing. Then, the tomato shoots was dried in the oven at $65{ }^{\circ} \mathrm{C}$ and weighed to record the dry weight of the tomato shoots. The dry weight of the tomato shoots was calculated as ton/feddan taking in consideration that the feddan area is $4200 \mathrm{~m}^{2}$ not $3600 \mathrm{~m}^{2}$.

\section{Statistical analysis}

The obtained results of two growth seasons were subjected to the analysis of variance using the least significant difference (L.S.D.) test at 5\% level of probability using the MSTAT-C v. 1.42 for completely randomized block design (in a split - split - plot) with three replicates. The L.S.D. test was used to compare between the various treatments means.

\section{RESULTS AND DISCUSSION}

1. Effects of the salinity and water stress on some tomato growth parameters under application of the potassium fertilization

\section{Tomato plant height}

The effects of irrigation water salinity and irrigation intervals on some tomato growth parameters under application of the potassium fertilization in the two growth seasons are given in Table 3. It can be seen that increasing irrigation water salinity level from $2.24 \mathrm{dS} \mathrm{m}^{-1}$ to $3.86 \mathrm{dS} \mathrm{m}^{-1}$ slightly decreased the tomato plant height. This slight decreased in the tomato plant height was significant $(p=$ 0.05 ) in the two tomato growth seasons. These results are in harmony with those reported by several authors. Maas and Grattan (1999) revealed that the salt-stressed plants are smaller and grow slower than the non salt-stressed plants, and require less water over a given time. Consequently, the salt-stressed plants deplete a smaller percentage of available soil water than the non saline plants, so they are less responsive to the frequent irrigations. In addition, Hajer et al. (2006) indicated that the height of tomato seedling was increased with time, while, it was decreased with increasing the salinity level $(1500,2500$, and $3500 \mathrm{ppm})$ in all the cultivars. Moreover, Tantawy et al. (2009) found that increasing the level of salinity (3000, 4000, and $5000 \mathrm{ppm})$ significantly reduce the tomato vegetative growth i.e. plant height, leaf area, chlorophyll, fresh and dry weights of shoot and potassium content. Similarly, Abbas (2010) found that the tomato plant height was decreased with increasing salinity $(0,1000,2000,3000,4000$, and 5000 ppm).

Increasing the irrigation intervals from 3 to 4 days slightly increased the tomato plant height in the two growth seasons (Table 3). This slight increase in tomato plant height was not significant $(p=0.05)$ in the two growth seasons.

Increasing the irrigation intervals from 3 to 5 days slightly decrease the tomato plant height in the two growth seasons (Table 3 ). This slight decrease in the tomato plant height was significant $(p=0.05)$ in the two growth seasons. This result is in harmony with those reported with several researchers. Pascual and Cabahug (2015) demonstrated that the tomato plants watered in three days interval experienced the most water deficit stress compared to the plants on other treatments (daily and 2 days interval). The results showed that significant reduction on the plant height was occurred when irrigation was done in three days interval. In addition, Imana et al. (2010) showed that the decrease in the plant growth as a result of water stress could be attributed to reduction in the transpiration rate that was observed.

The tomato plant height was increased by increasing the potassium fertilization level from 96 up to $144 \mathrm{~kg} \mathrm{~K} \mathrm{~K}_{2} \mathrm{O} /$ feddan in the two growth seasons as illustrated in Table 3. The increase in the tomato plant height was significant $(p=0.05)$ in the two growth seasons. This increase in the tomato plant height implies that application of the potassium fertilization to the soil alleviated the adverse effects of the salinity stress and water stress on the tomato plant height. Çolpan et al. (2013) reported that the tomato plant height was increased with increasing $\mathrm{K}$ application due to the vital role of $\mathrm{K}$ in the plant growth.

Tomato shoots fresh weight

It can be observed from Table 3 that increasing the irrigation water salinity level from $2.24 \mathrm{dS} \mathrm{m}^{-1}$ to $3.86 \mathrm{dS} \mathrm{m}^{-1}$ significantly decreased $(p=0.05)$ the tomato shoots fresh weight in the two growth seasons. This decrease in the tomato shoots fresh weight was accompanied with the slight decrease in the tomato plant height which was occurred when the tomato plants were irrigated with the well water No. 2 (Table 3). Yurtseven et al. (2005) showed that the tomato biomass yield was already reduced at the $2.5 \mathrm{dS} \mathrm{m}^{-1}$ salinity level and the reduction continued to increase as the salinity was increased from 2.5 to $10.0 \mathrm{dS} \mathrm{m}^{-1}$.

The tomato shoots fresh weight was significantly decreased $(p=0.05)$ by increasing the irrigation interval from 3 up to 5 days in the two growth seasons (Table 3 ). This significant decrease in the tomato shoots fresh weight was accompanied with the slight decrease in the tomato plant height which was occurred as a result of increasing the irrigation intervals from 3 up to 5 days (Table 3 ). This result is in agreement with those reported by several authors. Ahmed et al. (2017) found that the irrigation scheduling designated as the irrigation treatment $\mathrm{I}_{4}$ (irrigation every 4 days) produced the tomato biomass of $8.52 \mathrm{~g}$, while, the other irrigation treatment $\mathrm{I}_{7}$ (irrigation every 7 days) gave the tomato biomass of $5.56 \mathrm{~g}$. But with the highest biomass production which was obtained with the irrigation treatment $\mathrm{I}_{4}$, it appears that irrigating the tomato at 4 days interval is more favorable for the biomass production in the plant. Furthermore, Munns (2002) demonstrated that the initial reduction in the shoot growth is probably due to the hormonal signals generated by the roots.

Increasing the potassium fertilization level from 96 to $120 \mathrm{~kg} \mathrm{~K}_{2} \mathrm{O} /$ feddan increased the tomato shoots fresh weight in the two growth seasons as shown in Table 3. Increasing the potassium fertilization level from 96 to 144 $\mathrm{kg} \mathrm{K}_{2} \mathrm{O}$ /feddan decreased the tomato shoots fresh weight in the first growth season, whereas, it increased the tomato shoots fresh weight in the second growth season. This increase in the tomato shoots fresh weight suggests that application of the potassium fertilization to the soil alleviated the negative effects of the salinity stress and water stress on the tomato shoots fresh weight. These results are in agreement with those reported by several 
researchers. Malakouti et al. (2003) showed that potassium $(\mathrm{K})$ relieves water, salt and drought stresses, hence $\mathrm{K}$ reduces the crop water requirement. Because $\mathrm{K}$ has a dominant role in the opening and closing of the stomata, through which water is transpired from the leaves and $\mathrm{CO}_{2}$ enters the leaves. Plants deficient in $\mathrm{K}$ do not absorb sufficient quantities of water and, in consequence, they exhibit a temporary drought stress. In addition, Wang et al. (2013) concluded that maintaining an adequate $\mathrm{K}$ nutritional status is critical for the plant osmotic adjustment and for mitigating ROS (reactive oxygen species) damage as induced by the drought stress. An adequate $\mathrm{K}$ supply is essential for enhancing the drought resistance by increasing the root elongation and maintaining the cell membrane stability. Moreover, Chougui et al. (2014) concluded that the potassium fertilization did eliminate the deleterious effects of salinity on tomato (Lycopersicon esculentum Mill.; var: heintz), it have effects on increasing the physiomorphological traits of plants and reduce the accumulation of proline content

Table 3. Effects of irrigation water salinity and irrigation intervals on some tomato growth parameters under application of potassium fertilization in the two growth seasons.*

\begin{tabular}{|c|c|c|c|c|c|c|}
\hline \multirow[b]{2}{*}{ Treatment } & \multicolumn{3}{|c|}{ First growth season } & \multicolumn{3}{|c|}{ Second growth season } \\
\hline & $\begin{array}{l}\text { Plant height } \\
\text { (cm) }\end{array}$ & $\begin{array}{l}\text { Shoots fresh weight } \\
\text { (ton/feddan) }\end{array}$ & $\begin{array}{c}\text { Shoots dry weight } \\
\text { (ton/feddan) }\end{array}$ & $\begin{array}{l}\text { Plant Height } \\
\text { (cm) }\end{array}$ & $\begin{array}{c}\text { Shoots fresh weight } \\
\text { (ton/feddan) }\end{array}$ & $\begin{array}{l}\text { Shoots dry weight } \\
\text { (ton/feddan) }\end{array}$ \\
\hline$\overline{\mathrm{S}_{1} \mathrm{~T}_{1} \mathrm{~K}_{1}}$ & 112.00 & 1.816 & 0.214 & 109.00 & 1.480 & 0.184 \\
\hline $\mathrm{S}_{1} \mathrm{~T}_{1} \mathrm{~K}_{2}$ & 115.00 & 1.960 & 0.227 & 116.00 & 1.600 & 0.226 \\
\hline $\mathrm{S}_{1} \mathrm{~T}_{1} \mathrm{~K}_{3}$ & 119.00 & 1.728 & 0.258 & 114.00 & 1.544 & 0.248 \\
\hline Mean & 115.33 & 1.835 & 0.233 & 113.00 & 1.715 & 0.219 \\
\hline $\mathrm{S}_{1} \mathrm{~T}_{2} \mathrm{~K}_{1}$ & 116.00 & 1.840 & 0.211 & 114.00 & 1.632 & 0.187 \\
\hline $\mathrm{S}_{1} \mathrm{~T}_{2} \mathrm{~K}_{2}$ & 118.00 & 1.784 & 0.244 & 117.00 & 1.712 & 0.224 \\
\hline $\mathrm{S}_{1} \mathrm{~T}_{2} \mathrm{~K}_{3}$ & 122.00 & 1.720 & 0.290 & 115.00 & 1.656 & 0.266 \\
\hline Mean & 118.67 & 1.781 & 0.248 & 115.33 & 1.667 & 0.226 \\
\hline $\mathrm{S}_{1} \mathrm{~T}_{3} \mathrm{~K}_{1}$ & 110.00 & 1.760 & 0.209 & 111.00 & 1.560 & 0.199 \\
\hline $\mathrm{S}_{1} \mathrm{~T}_{3} \mathrm{~K}_{2}$ & 121.00 & 1.680 & 0.239 & 120.00 & 1.768 & 0.225 \\
\hline $\mathrm{S}_{1} \mathrm{~T}_{3} \mathrm{~K}_{3}$ & 123.00 & 1.624 & 0.264 & 117.00 & 1.816 & 0.235 \\
\hline Mean & 118.00 & 1.688 & 0.237 & 116.00 & 1.541 & 0.220 \\
\hline $\mathrm{S}_{2} \mathrm{~T}_{1} \mathrm{~K}_{1}$ & 109.00 & 1.680 & 0.219 & 107.00 & 1.584 & 0.197 \\
\hline $\mathrm{S}_{2} \mathrm{~T}_{1} \mathrm{~K}_{2}$ & 111.00 & 1.720 & 0.244 & 110.00 & 1.544 & 0.227 \\
\hline $\mathrm{S}_{2} \mathrm{~T}_{1} \mathrm{~K}_{3}$ & 114.00 & 1.760 & 0.250 & 109.00 & 1.568 & 0.238 \\
\hline Mean & 111.33 & 1.720 & 0.238 & 108.67 & 1.565 & 0.221 \\
\hline $\mathrm{S}_{2} \mathrm{~T}_{2} \mathrm{~K}_{1}$ & 106.00 & 1.664 & 0.232 & 105.00 & 1.560 & 0.208 \\
\hline $\mathrm{S}_{2} \mathrm{~T}_{2} \mathrm{~K}_{2}$ & 115.00 & 1.688 & 0.256 & 107.00 & 1.536 & 0.237 \\
\hline $\mathrm{S}_{2} \mathrm{~T}_{2} \mathrm{~K}_{3}$ & 108.00 & 1.704 & 0.248 & 112.00 & 1.552 & 0.246 \\
\hline Mean & 109.67 & 1.685 & 0.245 & 108.00 & 1.549 & 0.230 \\
\hline $\mathrm{S}_{2} \mathrm{~T}_{3} \mathrm{~K}_{1}$ & 99.00 & 1.544 & 0.245 & 100.00 & 1.352 & 0.217 \\
\hline $\mathrm{S}_{2} \mathrm{~T}_{3} \mathrm{~K}_{2}$ & 109.00 & 1.780 & 0.270 & 97.00 & 1.440 & 0.249 \\
\hline $\mathrm{S}_{2} \mathrm{~T}_{3} \mathrm{~K}_{3}$ & 102.00 & 1.456 & 0.252 & 106.00 & 1.432 & 0.241 \\
\hline Mean & 103.33 & 1.593 & $0.25 \overline{6}$ & 101.00 & 1.408 & 0.236 \\
\hline L.S.D at $5 \%$ level: & & & & & & \\
\hline Salinity (A) & 1.159 & 0.091 & N.S. & 1.129 & 0.108 & N.S. \\
\hline Intervals (B) & 0.797 & 0.053 & 0.029 & 0.777 & 0.044 & 0.010 \\
\hline Potassium (C) & 1.269 & 0.054 & 0.060 & 1.225 & 0.093 & 0.090 \\
\hline (A) $X(B)$ & N.S. & 0.083 & 0.010 & N.S. & 0.146 & 0.016 \\
\hline (A) X (C) & N.S. & 0.137 & 0.009 & N.S. & 0.131 & 0.015 \\
\hline (B) $\mathrm{X}(\mathrm{C})$ & N.S. & 0.265 & 0.012 & N.S. & 0.163 & 0.018 \\
\hline (A) X (B) X (C) & N.S. & 0.375 & 0.018 & 0.548 & 0.230 & 0.023 \\
\hline
\end{tabular}

* Each value represents means of three replicates.

\section{Tomato shoots dry weight}

It is obvious from Table 3 that increasing the irrigation water salinity level from $2.24 \mathrm{dS} \mathrm{m}^{-1}$ to $3.86 \mathrm{dS}$ $\mathrm{m}^{-1}$ slightly increased the tomato shoots dry weight in the two growth seasons. The slight increase in the tomato shoots dry weight was not significant $(p=0.05)$ in the two growth seasons. It is clear from Table 3 that increasing the irrigation intervals from 3 up to 5 days significantly increased $(p=0.05)$ the tomato shoots dry weight in the two growth seasons. Ayers and Westcot (1994) pointed out water stress between irrigations can often be eliminated by increasing the frequency of irrigations, thereby preventing the excessive root zone depletion caused by too long an interval between irrigations. By decreasing the interval between irrigations, a higher soil-water availability is maintained.

Increasing potassium fertilization level from 96 up to $144 \mathrm{~kg} \mathrm{~K} 2 \mathrm{O} /$ feddan increased the tomato shoots dry weight in the two growth seasons as shown in Table 3. The increase in the tomato shoots dry weight was not significant $(p=$
$0.05)$ in the two growth seasons. This increase in the tomato shoots dry weight indicates that application of the potassium fertilization to the soil alleviated the drastic effects of the salinity stress and water stress on the tomato shoots dry weight. This result is in agreement with those reported by several authors. Krauss (2003) reported that the function of $\mathrm{K}$ in the plants as an osmotically active cation and its involvement in controlling the water relationships in the plants given balanced fertilization with $\mathrm{K}$ is the unique opportunity to improve the tolerance of plants to the drought, frost, and salinity. Similarly, Fageria et al. (2011) reported that the application of high $\mathrm{K}^{+}$fertilization might enhance the capacity for osmotic adjustment of the tomato plants growing in the saline habitats.

The salinity stress and water stress effects on tomato growth (tomato health) as they delay the seed germination, reduce the germination percentage, induce the nutritional disorders, inhibit the shoot growth, and reduce the tomato plant growth. Finally, it can be recommended that to alleviate and manage the adverse effects of the 
salinity stress and water stress on the tomato growth (tomato health), the good cultural practices management to be followed are: (1) apply the appropriate and optimized requirements of potassium fertilization to the soil and (2) use the drip irrigation system as an irrigation management which affects on soil salinity buid-up and soil water content since it can keep a high soil water content and low salt concentration in the root zone.

2. Effects of the salinity and water stress on the tomato yield and yield components under application of the potassium fertilization

\section{Number of the tomato fruits per plant}

The effects of irrigation water salinity and intervals on the tomato yield and yield components under application of potassium fertilization in the two growth seasons is illustrated in Table 4. It can be seen that increasing irrigation water salinity level from $2.24 \mathrm{dS} \mathrm{m}^{-1}$ to $3.86 \mathrm{dS} \mathrm{m}^{-1}$ slightly increased the number of tomato fruits per plant in the two growth seasons. The slight increase in the number of tomato fruits per plant was not significant $(p=0.05)$ in the first growth season, whereas, it was significant $(p=0.05)$ in the second growth season. This result is in agreement with that reported by Al-Busaidi et al. (2010) who found that under the saline condition (3 and $\left.6 \mathrm{dS} \mathrm{m}^{-1}\right)$, it was observed that all the tomato plant parameters of the different varieties were reduced compared to the control except for the number of fruits.

Increasing the irrigation intervals from 3 to 4 days significantly increased $(p=0.05)$ the number of tomato fruits per plant (Table 4). Increasing the irrigation intervals from 3 to 5 days had no significant effect on the number of tomato fruits per plant in the first growth season, while, it result in a significant slight increase $(p=0.05)$ in the number of tomato fruits per plant in the second growth season. Increasing the potassium fertilization level from 96 to $120 \mathrm{~kg}$ $\mathrm{K}_{2} \mathrm{O} /$ feddan significantly increased $(p=0.05)$ the number of tomato fruits per plant in the first growth season, however, it gave a not significant slight increase $(p=0.05)$ in the number of tomato fruits per plant in the second growth season. Increasing the potassium fertilization level from 96 to $144 \mathrm{~kg} \mathrm{~K}_{2} \mathrm{O} /$ feddan gave a slight increase in the number of tomato fruits per plant in the first growth season, while, it resulted in a slight decrease in the number of tomato fruits per plant in the second growth season. The slight increase in the number of tomato fruits per plant in the first growth season and the slight decrease in the number of tomato fruits per plant in the second growth season were not significant. The increase in the number of tomato fruits per plant in the two growth seasons implies that application of the potassium fertilization to the soil alleviated the negative effects of the salinity stress and water stress on the number of tomato fruits per plant. This result is in agreement with that reported by Zayton et al. (2009) who indicated that increasing $\mathrm{K}^{+}$from 0.0 to 40,80 , and $120 \mathrm{~kg} /$ fed resulted in an increase in the tomato fruit number (FN) by about 9.8, 22, and 29.3\%, respectively. A significant interaction of the $\mathrm{EC}_{\mathrm{iw}}$ and $\mathrm{K}^{+}$on the FN was noted. These results declare that the effect of $\mathrm{EC}_{\mathrm{iw}}$ levels on the $\mathrm{FN}$ was more pronounced than the effect of the $\mathrm{K}^{+}$treatments.

Average tomato fruit weight

It can be observed from Table 4 that increasing the irrigation water salinity level from $2.24 \mathrm{dS} \mathrm{m}^{-1}$ to 3.86
$\mathrm{dS} \mathrm{m}^{-1}$ significantly decreased $(p=0.05)$ the average tomato fruit weight in the two growth seasons. This result is in agreement with those reported by several authors. Campos et al. (2006) reported that average tomato fruit weight was decreased from $53 \mathrm{~g}$ to $32 \mathrm{~g}$ for $\mathrm{EC}_{\mathrm{w}}=1.0$ and $5 \mathrm{dS} \mathrm{m}^{-1}$, respectively; the reduction was $9.2 \%$ for the unit increase of $\mathrm{EC}_{\mathrm{w}}$ above $1.0 \mathrm{dS} \mathrm{m}^{-1}$. Similarly, Malash et al. (2008) indicated that salinity (at $3 \mathrm{dS} / \mathrm{m}$ and above) significantly reduced the tomato fruit weight. Also, Using 100\% saline water in the irrigation significantly reduced the average weight of a fruit compared to those produced with fresh water. Moreover, Tantawy et al. (2009) pointed out that the average tomato fruit weight showed a negative response to the increment in the salinity level [saline solution with different EC strengths namely (3000, 4000, and 5000 ppm)].

Increasing the irrigation intervals from 3 to 4 days increased the average tomato fruit weight in the first growth season, while, it was slightly decreased the average tomato fruit weight in the second growth season. Increasing the irrigation intervals from 3 to 5 days slightly increased the average tomato fruit weight in the two growth seasons (Table 4). The increase in the average tomato fruit weight was not significant $(p=0.05)$ in the two growth seasons. Ismail et al. (2007) revealed that the average tomato fruit weight for 1-day irrigation frequency was higher than that of 3- days frequency. The most important factors, which have direct impact on the fruit weight and number, were the soil water content and soil temperatures. However, the soil water content affected mainly the fruit weight. The average tomato fruit weight was significantly increased $(p=0.05)$ with increasing the potassium fertilization level from 96 up to $144 \mathrm{~kg} \mathrm{~K}_{2} \mathrm{O}$ /feddan in the two growth seasons (Table 4). The increase in the number of tomato fruits per plant in the two growth seasons suggests that the application of potassium fertilization to the soil alleviated the adverse effects of the irrigation salinity stress and water stress on the average tomato fruit weight.

\section{Fresh tomato fruit yield}

It can be seen that increasing the irrigation water salinity level from $2.24 \mathrm{dS} \mathrm{m}^{-1}$ to $3.86 \mathrm{dS} \mathrm{m}^{-1}$ significantly decreased $(p=0.05)$ the fresh tomato fruit yield. The decrease in the fresh tomato fruit yield in the two growth seasons may be ascribed to the reduction in the average tomato fruit weight which was occurred when the tomato plants were irrigated with the well water No. 2 (Table 4). These results are in harmony with those reported by several authors. Ayres and Westcot (1994) pointed out that in the areas where irrigation management (leaching) cannot control salinity within the tolerance of a preferred crop, a yield loss will result unless an alternate crop more tolerant to the expected salinity is planted. In addition, Katerji et al. (1998) found that the reduction in the tomato fruit yield of the most saline treatment $\left(3.6 \mathrm{dS} \mathrm{m}^{-1}\right)$ is about $60 \%$. The reduction in the tomato fruit yield corresponds with a reduction in the fruit weight and in the number of fruit per plant. Furthermore, Shannon and Grieve (1999) showed that the cause of reduction of the yield under the salinity is a matter of controversy. It has been related either to the salt-induced disturbance of the water balance or to a loss of the leaf turgor, which can reduce the leaf expansion and consequently the photosynthetic leaf area. Moreover, Cuartero et al. (2006) reported that the reduction in the 
tomato yield was caused by reduced mean fruit weight as the salinity caused reduced water availability and biochemical and physiological disturbances in the rooting medium. Also, Malash et al. (2008) indicated that increasing the salinity of irrigation water gradually decreased the tomato yield. But reduction in the yield was significant only at $3 \mathrm{dS} / \mathrm{m}$ and above. This means that the salinity of irrigation water up to $2 \mathrm{dS} / \mathrm{m}$ could not significantly reduce the tomato yield. Drip irrigation had a favorable effect on tomato yield compared to the furrow irrigation, under both the saline and non-saline conditions. Similarly, Al-Harbi et al. (2015) found that irrigation with the saline water significantly reduced the total dry tomato biomass and total tomato fruits yield.

Table 4. Effects of irrigation water salinity and intervals on the tomato yield and yield components under application of potassium fertilization in the two growth seasons.*

\begin{tabular}{|c|c|c|c|c|c|c|}
\hline \multirow[b]{2}{*}{ Treatment } & \multicolumn{3}{|c|}{ First growth season } & \multicolumn{3}{|c|}{ Second growth season } \\
\hline & $\begin{array}{c}\text { Fruit number } \\
\text { per plant }\end{array}$ & $\begin{array}{l}\text { Average fruit } \\
\text { weight (g) }\end{array}$ & $\begin{array}{l}\text { Fresh tomato fruit } \\
\text { yield (ton/feddan) }\end{array}$ & $\begin{array}{c}\text { Fruit number } \\
\text { per plant }\end{array}$ & $\begin{array}{c}\text { Average fruit } \\
\text { weight (g) }\end{array}$ & $\begin{array}{l}\text { Fresh tomato fruit } \\
\text { yield (ton/feddan) }\end{array}$ \\
\hline $\mathrm{S}_{1} \mathrm{~T}_{1} \mathrm{~K}_{1}$ & 44.33 & 54.39 & 18.90 & 42.67 & 53.58 & 17.04 \\
\hline $\mathrm{S}_{1} \mathrm{~T}_{1} \mathrm{~K}_{2}$ & 43.81 & 55.35 & 19.40 & 41.92 & 54.03 & 18.12 \\
\hline $\mathrm{S}_{1} \mathrm{~T}_{1} \mathrm{~K}_{3}$ & 42.38 & 53.29 & 18.44 & 40.13 & 49.92 & 17.20 \\
\hline Mean & 43.51 & 54.34 & 18.91 & 41.57 & 52.51 & 17.45 \\
\hline $\mathrm{S}_{1} \mathrm{~T}_{2} \mathrm{~K}_{1}$ & 44.11 & 64.91 & 23.16 & 41.61 & 54.47 & 18.86 \\
\hline $\mathrm{S}_{1} \mathrm{~T}_{2} \mathrm{~K}_{2}$ & 44.98 & 66.38 & 23.84 & 42.51 & 56.57 & 19.36 \\
\hline $\mathrm{S}_{1} \mathrm{~T}_{2} \mathrm{~K}_{3}$ & 43.25 & 65.63 & 22.46 & 40.39 & 56.66 & 17.60 \\
\hline Mean & 44.11 & 65.64 & 23.15 & 41.50 & 55.90 & 18.61 \\
\hline $\mathrm{S}_{1} \mathrm{~T}_{3} \mathrm{~K}_{1}$ & 43.46 & 64.84 & 24.10 & 42.85 & 57.67 & 21.08 \\
\hline $\mathrm{S}_{1} \mathrm{~T}_{3} \mathrm{~K}_{2}$ & 44.49 & 68.00 & 24.98 & 43.16 & 62.09 & 21.46 \\
\hline $\mathrm{S}_{1} \mathrm{~T}_{3} \mathrm{~K}_{3}$ & 43.76 & 67.02 & 22.70 & 41.70 & 61.50 & 19.24 \\
\hline Mean & 43.90 & 66.62 & 23.93 & 42.57 & 60.42 & 20.59 \\
\hline $\mathrm{S}_{2} \mathrm{~T}_{1} \mathrm{~K}_{1}$ & 38.20 & 44.24 & 15.80 & 37.35 & 40.57 & 14.28 \\
\hline $\mathrm{S}_{2} \mathrm{~T}_{1} \mathrm{~K}_{2}$ & 43.51 & 48.50 & 16.88 & 43.08 & 43.64 & 15.04 \\
\hline $\mathrm{S}_{2} \mathrm{~T}_{1} \mathrm{~K}_{3}$ & 46.62 & 51.70 & 16.50 & 45.72 & 47.79 & 14.84 \\
\hline Mean & 42.78 & 48.15 & 16.39 & 42.05 & 44.00 & 14.72 \\
\hline $\mathrm{S}_{2} \mathrm{~T}_{2} \mathrm{~K}_{1}$ & 52.46 & 42.32 & 18.24 & 51.36 & 39.71 & 16.12 \\
\hline $\mathrm{S}_{2} \mathrm{~T}_{2} \mathrm{~K}_{2}$ & 49.11 & 44.49 & 17.40 & 48.66 & 40.38 & 15.72 \\
\hline $\mathrm{S}_{2} \mathrm{~T}_{2} \mathrm{~K}_{3}$ & 43.83 & 43.46 & 14.84 & 43.44 & 39.23 & 13.80 \\
\hline Mean & 48.47 & 43.42 & 16.83 & 47.82 & 39.77 & 15.21 \\
\hline $\mathrm{S}_{2} \mathrm{~T}_{3} \mathrm{~K}_{1}$ & 44.50 & 38.60 & 15.40 & 44.15 & 35.82 & 14.28 \\
\hline $\mathrm{S}_{2} \mathrm{~T}_{3} \mathrm{~K}_{2}$ & 41.05 & 40.56 & 13.32 & 42.45 & 37.10 & 12.60 \\
\hline $\mathrm{S}_{2} \mathrm{~T}_{3} \mathrm{~K}_{3}$ & 40.67 & 43.26 & 12.56 & 42.02 & 40.43 & 12.04 \\
\hline Mean & 42.07 & 40.81 & 13.76 & 42.87 & 37.78 & 12.97 \\
\hline L.S.D at $5 \%$ level: & & & & & & \\
\hline Salinity (A) & 0.934 & 6.788 & 1.382 & 0.824 & 5.723 & 0.454 \\
\hline Intervals (B) & 0.745 & N.S. & 0.391 & 0.671 & N.S. & 0.407 \\
\hline Potassium (C) & 0.809 & 3.763 & 0.524 & 0.029 & 3.361 & 0.577 \\
\hline (A) X (B) & 1.321 & 5.760 & 0.585 & N.S. & 5.310 & 0.575 \\
\hline (A) X (C) & N.S. & N.S. & 0.740 & 0.003 & N.S. & 0.003 \\
\hline (B) $\mathrm{X}$ (C) & 1.455 & N.S. & 0.907 & N.S. & N.S. & 1.000 \\
\hline (A) X (B) X (C) & 2.058 & N.S. & 1.282 & 1.458 & N.S. & 1.128 \\
\hline
\end{tabular}

* Each value represents means of three replicates.

Increasing the irrigation intervals from 3 to 4 days significantly increased $(p=0.05)$ the fresh tomato fruit yield in the two growth seasons (Table 4). Increasing the irrigation intervals from 3 to 5 days significantly increased ( $p$ $=0.05)$ the fresh tomato fruit yield. These results are in harmony with those reported by several authors. Ayres and Westcot (1994) pointed out that crop production potential using a particular irrigation water can range from 100 percent down to zero but there are often factors other than water quality which affect yield. Reduced yields or crop damage can be expected for most crops when there is a shortage of water for a significant period of time. In addition, Hanson et al. (2006) showed that a significant linear regression relationship between the marketable tomato yield and the applied water was found with the yield decreasing as the applied water was decreased. Nevertheless, Ismail et al. (2007) reported that the most important factors, which have direct impact on the tomato fruit weight and number, were the soil water content and soil temperatures. However, soil water content affected mainly the fruit weight. Moreover, Farooq et al. (2008) demonstrated that the scarcity of water is a severe environmental constraint to the plant productivity. Drought-induced loss in the crop yield probably exceeds the losses from all other causes, since both the severity and duration of the stress are critical. The drought stress reduces the leaf size, stem extension, and root proliferation, disturbs plant water relations, and reduces the water-use efficiency. Likewise, Rahil et al. (2013) revealed that the total and marketable tomato fruit yield was decreased with increasing salinity level particularly in the treatments irrigated every three days. Also, Pascual and Cabahug (2015) reported that looking at the individual effect of the irrigation frequency (daily, two days interval, and three days interval) to the yield of tomato, a general reduction in the yield was observed as the stress level experienced by the plants increased.

Increasing the potassium fertilization level from 96 to $120 \mathrm{~kg} \mathrm{~K} 2 \mathrm{O} /$ feddan slightly increased the fresh tomato fruit yield in the two growth seasons as shown in Table 4 . Increasing the potassium fertilization level from 96 to $144 \mathrm{~kg}$ $\mathrm{K}_{2} \mathrm{O}$ /feddan significantly decreased the fresh tomato fruit yield in the two growth seasons. The slightly increase in the fresh tomato fruit yield was significant $(p=0.05)$ in the two growth seasons. This increase in the fresh tomato fruit yield suggests that application of the potassium fertilization to the soil alleviated the negative effects of the salinity stress and water stress on the fresh tomato fruit yield. These results are 
in agreement with those reported by Akhtar et al. (2010) who showed that the yield of tomatoes was significantly increased with $\mathrm{K}$ application. Tomato is a high $\mathrm{K}$ requiring crop and $\mathrm{K}$ application increased the yield though soil had relatively high plant available $\mathrm{K}$.

3. Effects of the salinity and water stress on the tomato fruit quality parameters under application of the potassium fertilization

Total Soluble Solids (T.S.S. \%)

The effect of irrigation water salinity and irrigation intervals on some tomato fruit quality parameters under application of the potassium fertilization in the two growth seasons is summarized in Table 5. It can be seen that increasing irrigation water salinity level from $2.24 \mathrm{dS} \mathrm{m}^{-1}$ to $3.86 \mathrm{dS} \mathrm{m}^{-1}$ significantly increased $(p=0.05)$ the total soluble solids of tomato in the two growth seasons. This result is in harmony with those reported by several authors. Yurtseven et al. (2005) indicated that increasing the salinity levels $\left(1.25,2.5,5\right.$, and $\left.10 \mathrm{dS} \mathrm{m}^{-1}\right)$ resulted in higher soluble solid content (SSC) and decreased the $\mathrm{pH}$ of the fruit juice. In addition, Krauss et al. (2006) revealed that the higher EC values (E.C. 6.5 and $10 \mathrm{dS} \mathrm{m}^{-1}$ ) caused an increase of the total soluble solids and organic acids, parameters determining the taste of tomatoes. As all desirable characteristics in the freshly produced tomato increased when exposed to salinity, salinity itself constitutes an alternative method of quality improvement. Moreover, it can compensate for the loss of yield by the higher inner quality due to changing demands by the market and the consumer. Also, Malash et al. (2007) showed that an increasing ratio of saline water in the irrigation caused an increase in fruit TSS content. Zayton et al. (2009) showed that increasing $\mathrm{EC}_{\mathrm{iw}}$ strongly increased the TSS of tomato. Increasing the $\mathrm{EC}_{\mathrm{iw}}$ to 5 and $10 \mathrm{dS} / \mathrm{m}$ increased the TSS values by about 48.4 and $98.2 \%$, respectively. These results confirmed that the TSS of tomato was strictly related to the $\mathrm{EC}_{\mathrm{iw}}$.

The total soluble solids of tomato was significantly increased $(p=0.05)$ by increasing the irrigation interval from 3 up to 5 days in the two growth seasons (Table 5). This significant increase in the total soluble solids of tomato may be due to the reduction in water intake by the fruits. This result is in agreement with those reported by Mitchell et al. (1991) who showed that deficit irrigation increased fruit soluble solids levels and, led to higher concentrations of hexoses, citric acid, and potassium.

Increasing the potassium fertilization level from 96 up to $144 \mathrm{~kg} \mathrm{~K}_{2} \mathrm{O}$ /feddan significantly increased ( $p=0.05$ ) the total soluble solids of tomato in the two growth seasons as shown in Table 5. This increase in the tomato shoots fresh weight suggests that application of the potassium fertilization to the soil alleviated the negative effects of the salinity stress and water stress on the total soluble solids of tomato. These results are in agreement with those reported by several researchers. Çolpan et al. (2013) showed that the ${ }^{\circ}$ Brix value of fruit was increased with increasing $\mathrm{K}$ doses until $120 \mathrm{~kg} \mathrm{~K} 2 \mathrm{O} / \mathrm{ha}$, after which it decreased. Moreover, Amjad et al. (2014) indicated that the application of potassium increases the yield and quality of tomato fruits in saline soil. The improvement in the fruit quality characteristics (TSS and dry matter percent) in response to salinity stress could be due to decreased fruit water content. It was concluded that application of potassium increases yield and quality of tomato fruits in the saline soil, and it could be used as an effective practice to produce even a saltsensitive species like tomato under saline conditions.

Tomato fruits marketability [(shelf life duration (days)] It is obvious from Table 5 that increasing the irrigation water salinity level from $2.24 \mathrm{dS} \mathrm{m}^{-1}$ to $3.86 \mathrm{dS} \mathrm{m}^{-1}$ significantly increased $(p=0.05)$ the tomato fruits marketability (shelf life) in the two growth seasons (Table 5). Increasing the irrigation intervals from 3 up to 5 days significantly increased $(p=0.05)$ the tomato fruits marketability in the two growth seasons (Table 5). This significant increase in the tomato fruits marketability was accompanied with the increase in the tomato total solids which was occurred as a result of increasing the irrigation intervals from 3 up to 5 days (Table 5). Grieve (2011) pointed out that for fresh fruit consumption, tomato quality is determined by shape, size, color, firmness, texture, absence of blemishes (shoulder cracking, BER), shelf life, aroma, flavor, and nutritional benefits. Increasing the potassium fertilization level from 96 up to $144 \mathrm{~kg} \mathrm{~K}_{2} \mathrm{O} /$ feddan significantly increased $(p=0.05)$ the tomato fruits marketability in the two growth seasons as shown in Table 5. This increase in the tomato shelf life indicates that application of the potassium fertilization to the soil alleviated the drastic effects of the salinity stress and water stress on the tomato fruits marketability. This result is in agreement with those reported by several authors.

Tomato fruit dry weight

It is clear that increasing the irrigation water salinity level from $2.24 \mathrm{dS} \mathrm{m}^{-}$to $3.86 \mathrm{dS} \mathrm{m}^{-1}$ significantly decreased $(p=0.05)$ the tomato fruit dry weight in the two growth seasons. The significant decrease in the tomato fruit dry weight was accompanied with the decrease in the fresh tomato fruit yield which was occurred as a result of increasing the irrigation water salinity from 2.24 to 3.86 $\mathrm{dS} / \mathrm{m}$ (Table 4). This result is in harmony with those reported with several authors. Babu et al. (2012) found that dry matter content of mature tomato fruits was found to be decreased with application of elevated salt treatment $(25,50$, 100, 150, and $200 \mathrm{mM} \mathrm{NaCl}$ ). Also, Amjad et al. (2014) reported that the improvement in tomato fruit dry matter percent in response to salinity stress could be due to decreased fruit water content.

It can be seen from Table 5 that increasing the irrigation intervals from 3 to 4 days slightly increased the tomato fruit dry weight in the two growth seasons. This slight increase in the tomato fruit dry weight was not significant $(p=0.05)$ in the two growth seasons. However, increasing the irrigation intervals from 3 to 5 days slightly decreased the tomato fruit dry weight in the two growth seasons. This slight decrease in the tomato fruit dry weight was not significant $(p=0.05)$ in the two growth seasons. This result is consistent with those reported with several researchers.

Increasing the potassium fertilization level from 96 to $120 \mathrm{~kg} \mathrm{~K}_{2} \mathrm{O}$ /feddan increased the tomato fruit dry weight in the two growth seasons. Increasing the potassium fertilization level from 96 to $144 \mathrm{~kg}$ $\mathrm{K}_{2} \mathrm{O}$ /feddan slightly decreased the tomato fruit dry weight in the two growth seasons as presented in Table 5. The increase in the tomato fruit dry weight was not significant $(p=0.05)$ in the two growth seasons. This 
increase in the tomato fruit dry weight suggests that application of the potassium fertilization to the soil alleviated the negative effects of the salinity stress and water stress on the tomato fruit dry weight.

Table 5. Effects of irrigation water salinity and intervals on some tomato fruit quality parameters under application of potassium fertilization in the two growth seasons.*

\begin{tabular}{|c|c|c|c|c|c|c|}
\hline \multirow{2}{*}{ Treatment } & \multicolumn{3}{|c|}{ First growth season } & \multicolumn{3}{|c|}{ Second growth season } \\
\hline & TSS (\%) & Shelf life (days) & Dry mass (ton/feddan) & TSS(\%) & Shelf life (days) & Dry mass (ton/feddan) \\
\hline $\mathrm{S}_{1} \mathrm{~T}_{1} \mathrm{~K}_{1}$ & 4.50 & 3.00 & 1.565 & 5.50 & 3.50 & 1.363 \\
\hline $\mathrm{S}_{1} \mathrm{~T}_{1} \mathrm{~K}_{2}$ & 5.00 & 3.50 & 2.040 & 5.00 & 3.50 & 1.622 \\
\hline $\mathrm{S}_{1} \mathrm{~T}_{1} \mathrm{~K}_{3}$ & 5.00 & 4.00 & 2.169 & 6.00 & 4.50 & 1.885 \\
\hline Mean & 4.83 & 3.50 & 1.925 & 5.50 & 3.83 & 1.623 \\
\hline $\mathrm{S}_{1} \mathrm{~T}_{2} \mathrm{~K}_{1}$ & 5.50 & 3.00 & 1.686 & 6.00 & 3.50 & 1.522 \\
\hline $\mathrm{S}_{1} \mathrm{~T}_{2} \mathrm{~K}_{2}$ & 5.50 & 4.00 & 2.129 & 6.00 & 4.50 & 1.721 \\
\hline $\mathrm{S}_{1} \mathrm{~T}_{2} \mathrm{~K}_{3}$ & 5.00 & 5.50 & 2.286 & 6.00 & 5.50 & 1.944 \\
\hline Mean & 5.33 & 4.17 & 2.034 & 6.00 & 4.50 & 1.729 \\
\hline $\mathrm{S}_{1} \mathrm{~T}_{3} \mathrm{~K}_{1}$ & 5.00 & 3.50 & 1.617 & 6.00 & 4.00 & 1.469 \\
\hline $\mathrm{S}_{1} \mathrm{~T}_{3} \mathrm{~K}_{2}$ & 5.50 & 5.50 & 2.030 & 6.50 & 5.50 & 1.566 \\
\hline $\mathrm{S}_{1} \mathrm{~T}_{3} \mathrm{~K}_{3}$ & 6.00 & 5.50 & 2.129 & 6.50 & 5.50 & 1.780 \\
\hline Mean & 5.50 & 4.83 & 1.925 & 6.33 & 5.00 & 1.605 \\
\hline $\mathrm{S}_{2} \mathrm{~T}_{1} \mathrm{~K}_{1}$ & 6.00 & 3.50 & 1.403 & 6.50 & 4.00 & 1.242 \\
\hline $\mathrm{S}_{2} \mathrm{~T}_{1} \mathrm{~K}_{2}$ & 7.50 & 4.50 & 1.561 & 7.00 & 4.50 & 1.336 \\
\hline $\mathrm{S}_{2} \mathrm{~T}_{1} \mathrm{~K}_{3}$ & 8.00 & 4.50 & 1.537 & 8.00 & 5.00 & 1.395 \\
\hline Mean & 7.17 & 4.17 & 1.500 & 7.17 & 4.50 & 1.324 \\
\hline $\mathrm{S}_{2} \mathrm{~T}_{2} \mathrm{~K}_{1}$ & 6.00 & 4.00 & 1.528 & 7.00 & 5.00 & 1.331 \\
\hline $\mathrm{S}_{2} \mathrm{~T}_{2} \mathrm{~K}_{2}$ & 7.50 & 5.00 & 1.683 & 7.50 & 5.50 & 1.476 \\
\hline $\mathrm{S}_{2} \mathrm{~T}_{2} \mathrm{~K}_{3}$ & 8.50 & 5.50 & 1.349 & 8.50 & 6.00 & 1.254 \\
\hline Mean & 7.33 & 4.83 & 1.520 & 7.67 & 5.50 & 1.354 \\
\hline $\mathrm{S}_{2} \mathrm{~T}_{3} \mathrm{~K}_{1}$ & 7.00 & 4.50 & 1.561 & 7.50 & 5.00 & 1.336 \\
\hline $\mathrm{S}_{2} \mathrm{~T}_{3} \mathrm{~K}_{2}$ & 8.00 & 5.50 & 1.459 & 8.50 & 5.50 & 1.326 \\
\hline $\mathrm{S}_{2} \mathrm{~T}_{3} \mathrm{~K}_{3}$ & 8.50 & 6.00 & 1.291 & 9.00 & 6.00 & 1.228 \\
\hline Mean & 7.83 & 5.33 & 1.437 & 8.33 & 5.50 & 1.297 \\
\hline L.S.D at $5 \%$ level: & & & & & & \\
\hline Salinity (A) & 0.095 & 0.208 & 0.152 & 0.061 & 0.109 & 0.109 \\
\hline Intervals (B) & 0.033 & 0.117 & 0.143 & 0.033 & 0.045 & 0.115 \\
\hline Potassium (C) & 0.045 & 0.120 & 0.231 & 0.045 & 0.045 & 0.209 \\
\hline (A) $\mathrm{X}(\mathrm{B})$ & 0.033 & 0.086 & N.S. & 0.033 & 0.033 & 0.263 \\
\hline (A) X (C) & 0.029 & 0.075 & 0.073 & 0.029 & 0.029 & 0.518 \\
\hline (B) $\mathrm{X}$ (C) & N.S. & 0.943 & 0.893 & N.S. & 0.361 & 0.634 \\
\hline (A) X (B) X (C) & 0.029 & 0.190 & 0.126 & 0.029 & 0.072 & 0.090 \\
\hline
\end{tabular}

\section{CONCLUSION}

The present study attempts to increase salt tolerance of tomato plants irrigated with different irrigation water salinity and stress levels by adding different potassium fertilization levels, which might minimize the deleterious effects of salinity and water stress on crop yield, quality and growth parameters of tomato plants under drip irrigation system. Increasing potassium fertilization level from 96 up to $144 \mathrm{~kg} \mathrm{~K}_{2} \mathrm{O}$ /feddan increased the tomato plant height, tomato shoots dry weight, average tomato fruit weight, total soluble solids of tomato, and tomato fruits marketability. The increase in the tomato plant height, tomato shoots fresh weight, tomato shoots dry weight, number of tomato fruits per plant, average tomato fruit weight, fresh tomato fruit yield, total soluble solids of tomato, tomato fruits marketability, and tomato fruit dry weight implies that application of the potassium fertilization to the soil alleviated the adverse effects of the salinity stress and water stress on the tomato growth, tomato yield, and tomato fruit quality.

Increasing irrigation water salinity level from 2.24 $\mathrm{dS} \mathrm{m}{ }^{-1}$ to $3.86 \mathrm{dS} \mathrm{m}^{-1}$ decreased the tomato plant height, tomato shoots fresh weight, average tomato fruit weight, fresh tomato fruit yield, and tomato fruit dry weight, while, it increased the tomato shoots dry weight, number of tomato fruits per plant, total soluble solids of tomato, and tomato fruits marketability (shelf life) in the two growth seasons. Increasing irrigation interval from 3 up to 5 days decreased tomato shoots fresh weight in two growth seasons, however, it increased tomato shoots dry weight, total soluble solids, and tomato fruits marketability in two growth seasons. It could be recommended that to alleviate and manage adverse effects of salinity and water stress on tomato growth, yield, and fruit quality, good cultural practices management to be followed are: (1) irrigate tomato plants every 4 days, using drip irrigation system (2) applying appropriate and optimized requirements of potassium fertilization to soils namely $120 \mathrm{~kg} \mathrm{~K}_{2} \mathrm{O}$ /feddan.

\section{REFERENCES}

Abbas, K. F. (2010). Effect of salinity on seed germination and growth of tomato seedlings (Lycopersicon esculentum). J. Thi-Qar Sci. Vol.2 (3), pp. 78 - 92. ISSN 1991- 8690.

Ahmed, N. U.; Mahmud, N. U.; Zaman, Md. A.; Ferdous, Z.; and Halder, S. C. (2017). Effect of different salinity level on tomato (Lycopersicon esculentum) production under climate change condition in Bangladesh. Annual Research \& Review in Biology, Vol. 13 (3), pp. 1 - 9; Article no.ARRB.33613. ISSN: 2347-565X, NLM ID: 101632869.

Akhtar, M. E.; Khan, M. Z.; Rashid, M. T.; Ahsan, Z. and Ahmad, S. (2010). Effect of potash application on yield and quality of tomato (Lycopersicon esculentum mill.). Pak. J. Bot., Vol. 42 (3), pp. 16951702. 
Al-Busaidi, A.; Al-Rawahy, S. A.; and Ahmed, M. (2010). Growing Tomato in Salty Soil: Screening Response of Different Tomato Cultivars to Saline Irrigation. A Monograph on Management of Salt-Affected Soils and Water for Sustainable Agriculture, Sultan Qaboos University, pp. 25 - 33.

Al-Harbi, A. R.; Al-Omran, A. M.; Alenazi, M. M.; and Wahb-Allah, M. A. (2015). Salinity and deficit irrigation influence tomato growth, yield and water use efficiency at different developmental stages. . Int. J. Agric. Biol., Vol. 17, pp. 241-250.

Amjad, M.; Akhtar, J.; Anwar-ul-haq, M.; Imran, Sh.; and Jacobsen, S. E. (2014). Soil and foliar application of potassium enhances fruit yield and quality of tomato under salinity. Turkish Journal of Biology, Vol. 38, pp. 208 - 218. doi:10.3906/biy-1305-54

APHA (2012). Standard Methods for the Examination of Water and Waste Water. 22nd Edition, American Public Health Association, American Water Works Association, Water Environment Federation.

Avery, B. W. and Bascomb, C. L. (1982). Soil survey laboratory methods. Technical Monograph No. 6. Soil Survey, Harpenden, UK.

Ayers, R. S. and Westcot, D. W. (1994). Water quality for agriculture. Irrigation and drainage paper 29, FAO, Rome, 174 p, ISBN 9251022631.

Babu, M. A.; Singh, D.; and Gothandam, K. M. (2012). The effect of salinity on growth, hormones and mineral elements in leaf and fruit of tomato cultivar pkm1. The Journal of Animal and Plant Sciences, Vol. 22 (1), pp. 159-164.

Black, C. A.; Evans, D. D.; White J. L.; Enminger, L. E.; and Clark, F. F. (1965). Methods of Soil Analysis. Soil sci., Am. Inc. Publ., Madison, Wisconsin, USA.

Campos, C. A. B.; Fernandes, P. D.; Gheyi, H. R.; Blanco, F. F.; Gonçalves C. B.; and Campos S. A. F. (2007). Yield and fruit quality of industrial tomato under saline irrigation. Sci. Agric. (Piracicaba, Braz.), Vol. 63 (2), pp. $146-152$.

Chapman, H. D. and Pratt, F. (1961). Methods of Analysis of Soils, Plants, and Water. Univ. Calf.

Chougui, S.; Houria, B.; and Mébarek, B. (2014). Interactive effects of salinity and potassium on physiomorphological traits of tomato (Lycopersicon esculentum Mill.; var: heintz). Agric. Biol. J. N. Am., Vol. 5 (3), pp. 135 - 143. ISSN Print: 21517517, ISSN Online: 2151-7525, doi:10.5251/abjna. 2014.5.3.135.143. (C) 2014, ScienceHuß, http://www. scihub.org/ABJNA.

Çolpan, E.; Zengin, M.; and Özbahçe, A. (2013). The effects of potassium on the yield and fruit quality components of stick tomato. Hort. Environ. Biotechnol., Vol. 54 (1), pp. 20 - 28. doi 10.1007/s13580-013-0080-4.

Cuartero, J. and Fernandez-Munoz, R. (1999). Tomato and salinity. Scientia Horticulturae, Vol. 78, pp. 83 - 125.

El Bedawy, R. (2014). Water Resources Management: Alarming Crisis for Egypt. Journal of Management and Sustainability; Vol. 4, No. 3, pp. 108 - 124. ISSN 1925-4725 E-ISSN 1925-4733.

El-Nahrawy, M. A. (2011). Country pasture/forage resource profiles (Egypt). C FAO 2011.
Fageria, N. K.; Gheyi, H. R.; and Moreira, A. (2011). Nutrient bioavailability in salt affected soils. Journal of Plant Nutrition, Vol. 34 (7), pp. 945 - 962, DOI: $10.1080 / 01904167.2011 .555578$. https://doi.org/10.1080/01904167.2011.555578

Farooq, M.; Wahid, A.; Kobayashi, N.; Fujita, D.; and Basra, S.M.A. (2008). Plant drought stress: effects, mechanisms and management. Agron. Sustain. Dev., Vol. 29, pp. 185 - 212. DOI: 10.1051/agro:2008021.

Hajer, A. S.; Malibari, A. A.; Al-Zahrani, H. S.; and Almaghrabi, O.A. (2006). Responses of three tomato cultivars to sea water salinity 1 . Effect of salinity on the seedling growth. African Journal of Biotechnology Vol. 5 (10), pp. 855-861. ISSN 1684 5315 (C) 2006 Academic Journals.

Hanson, B. R.; Hutmacher, R. B.; and May, D. M. (2006). Drip irrigation of tomato and cotton under shallow saline ground water conditions. Irrigation and Drainage Systems, Vol. 20, pp. 155-175. C Springer 2006. doi: 10.1007/s10795-005-9000-9

Hasanuzzaman, M.; Nahar, K.; Fujita, M.; Ahmad, P.; Chandna, R.; Prasad, M. N. V.; and Ozturk, M. (2013). Enhancing plant productivity under salt stress - relevance of poly-omics. In: Ahmad P, Azooz MM, Prasad MNV (eds) Salt stress in plants: omics, signaling and responses. Springer, Berlin, pp 113-156. DOI 10.1007/978-1-4614-6108-1_6

Imana, C.; Aguyoh, J. N.; and Opiyo, A. (2010). Growth and physiological changes of tomato as influenced by soil moisture levels. Second RUFORUM Biennial Meeting 20 - 24 September 2010, Entebbe, Uganda.

Ismail, M. S.; Ozawa, K.; and Khondaker, N. A. (2007). Effect of irrigation frequency and timing on tomato yield, soil water dynamics and water use efficiency under drip irrigation. Eleventh International Water Technology Conference, IWTC11 2007 Sharm ElSheikh, Egypt.

Jackson, M. L. (1973). Methods of chemical analysis. Prentic Hall., EngleWood Cliffs, N. T. J.

Katerji, N.; van Hoorn, J.W.; Hamdy, A.; and Mastrorilli, M. (1998). Response of tomatoes, a crop of indeterminate growth, to soil salinity. Agricultural Water Management, Vol. 38, pp. 59 - 68. (C) 1998 Elsevier Science B.V. All rights reserved.

Krauss, A. (2001). Balanced fertilization in the WANA region; Session 1, Introduction to potassium fertilization. In: Potassium and water management in West Asia and North Africa. Edited by Johnston A. E. (2003). Regional Workshop of the International Potash Institute in cooperation with The National Center for Agricultural Research and Technology Transfer, Amman, Jordan 5-6 November 2001, 7-37. Printing: Imprimerie de Saint-Louis, France. (C) All rights held by: International Potash Institute.

Maas, E.V. and Grattan, S.R. (1999). Crop Yields as Affected by Salinity. In: Skaggs, R.W. and van Schilfgaarde, J., Eds., Agricultural Drainage Agronomy Monograph No. 38, ASA, Madison, pp. 55-108.

Mahajan, Sh. and Tuteja, N. (2005). Cold, salinity and drought stresses: An overview. Archives of Biochemistry and Biophysics, Vol. 444, pp. $139-$ 158. doi:10.1016/j.abb.2005.10.018. 
Malash, N. M.; Flowers, T. J.; and Ragab, R. (2007). Effect of irrigation methods, management and salinity of irrigation water on tomato yield, soil moisture and salinity distribution. Irrig. Sci. Vol. 26, pp. $313-$ 323. DOI 10.1007/s00271-007-0095-7

Malash, N. M.; Ali, F. A.; Fatahallaa, M. A.; khatab, E. A.; Hatemb, M. K.; and Tawfic, S. (2008). Response of tomato to irrigation with saline water applied by different irrigation methods and water management strategies. International Journal of Plant Production, Vol. 2 (2), pp. 101 - 116. ISSN: 1735-6814 (Print), 1735-8043 (Online)

Malakouti, M. J.; Vaziri, J.; Nouri, A.A.; Ramazanpoor, M. R.; Mahdavi, M.; and Rasteghar, H. (2003). Crop yield and water use efficiency as affected by potassium fertilization. In: Potassium and water management in West Asia and North Africa. Regional Workshop of the International Potash Institute in cooperation with in cooperation with Technology Transfer, Amman, Jordan, 5-6 November 2001, pp. $76-82$.

Munns, R. (2002). Comparative physiology of salt and water stress. Plant Cell Environ., Vol. 25, pp. 239-250. C 2002 Blackwell Science Ltd.

Osman, K. T. (2018). Saline and Sodic Soils. In: Management of Soil Problems. (C) Springer International Publishing AG, part of Springer Nature 2018, pp. 255 - 298. https://doi.org/10.1007/978-3319-75527-4 10 .

Page, A. L.; Miller, R. H.; and Keeney, D. R. (1982): Methods of soil analysis; 2. Chemical and microbiological properties, 2. Aufl. 1184 S., American Soc. of Agronomy (Publ.), Madison, Wisconsin, USA.

Pascual, P. R. L. and Cabahug, J. P. (2015). Effect of different fertilizer schemes and irrigation intervals on tomatoes' response to water shortage. Tropical Technology Journal, Vol. 19 (1), Article 6, pp. $1-4$. ISSN: 2199-8698. doi 10.7603/s40934-015-0006-0.
Phocaides, A. (2000). Technical handbook on pressurized irrigation techniques, Food and Agriculture Organization of the United Nations. Rome.

Rahil, M.; Hajjeh, H.; and Qanadillo, A. (2013). Effect of Saline Water Application through Different Irrigation Intervals on Tomato Yield and Soil Properties. Open Journal of Soil Science, Vol., 3, pp. $143-147$.

Saad, A. F.; Hedia, R. M. R.; and Mokhtar, A. M. A. (2013). Effect of irrigation scheduling using drainage water on moisture and salinity of root zone and leaf water potential of tomato. Alex. J. Agric. Res. Vol. 58, No.1, pp. 29 - 38.

Tantawy, A. S.; Abdel-Mawgoud, A. M. R.; El-Nemr, M. A.; and Chamoun, Y. G. (2009). Alleviation of salinity effects on tomato plants by application of amino acids and growth regulators. European Journal of Scientific Research, Vol. 30 (3), pp. $484-494$. ISSN 1450-216X. C EuroJournals Publishing, Inc. 2009.

Wang, M.; Zheng, Q.; Shen, G.; and Guo, Sh. (2013). The critical role of potassium in plant stress response. Int. J. Mol. Sci., Vol. 14, pp. 7370 - 7390. ISSN 14220067. doi:10.3390/ijms14047370.

Yurtseven, E.; Kesmez, G. D.; and Ulukara, A. (2005). The effects of water salinity and potassium levels on yield, fruit quality and water consumption of a native central anatolian tomato species (Lycopersicon esculantum). Agricultural Water Management, Vol. 78, pp. 128 - 135. doi:10.1016/j.agwat.2005.04.018. (C) 2005 Elsevier.

Zayton, A.; El-Shafei, A.; Allam, Kh.; and Mourad, M. (2009). Effect of water salinity and potassium fertilizer levels on tomato productivity and water consumption in Siwa Oasis. Misr J. Ag. Eng., 26 (1), pp. $107-131$.

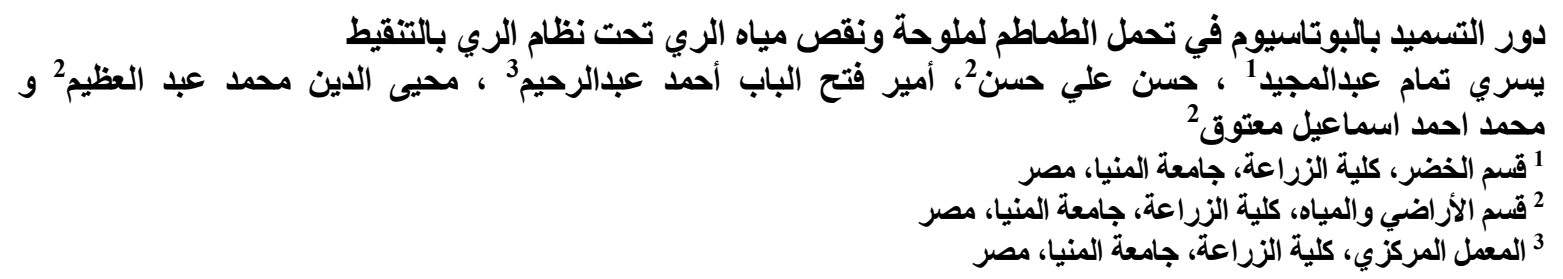

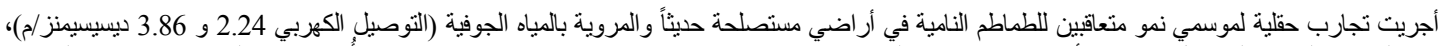

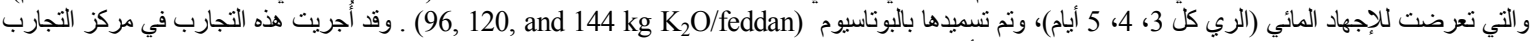

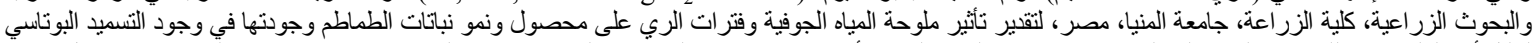

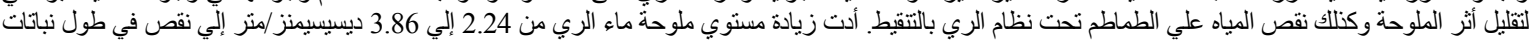

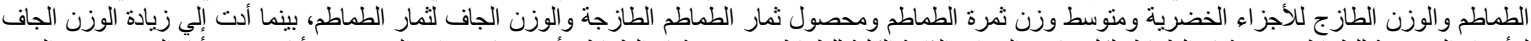

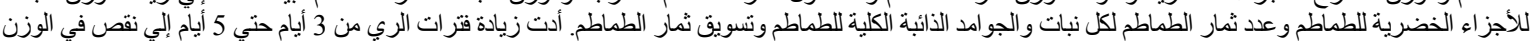

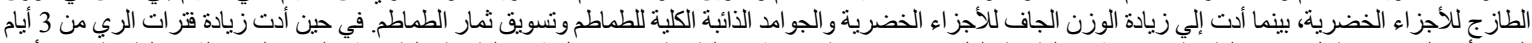

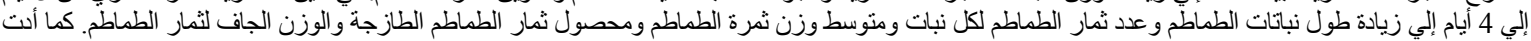

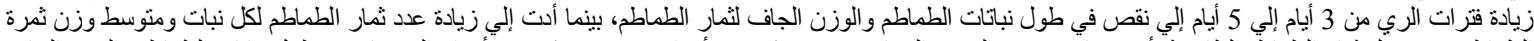

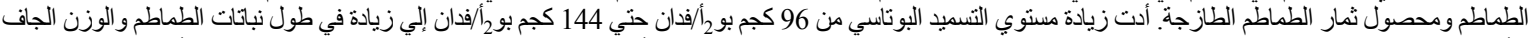

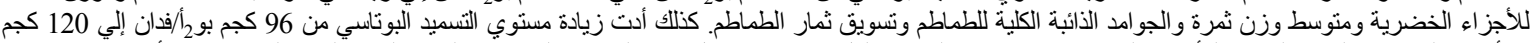

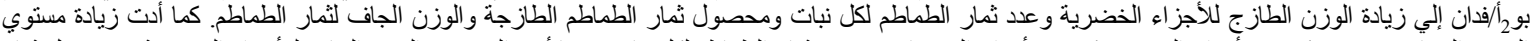

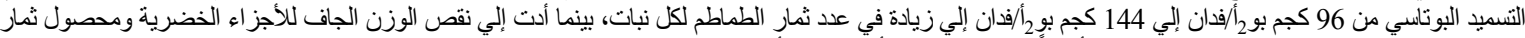

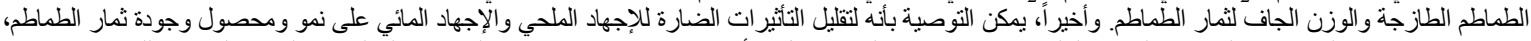

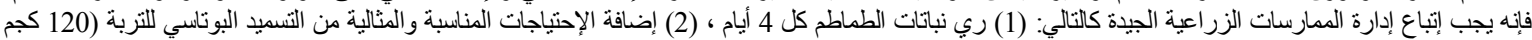

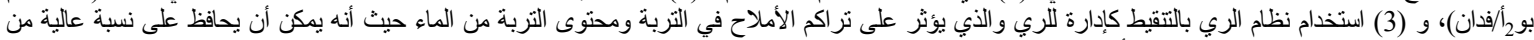

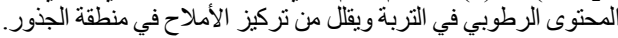

